\title{
Isotopic values of plants in relation to water availability in the Eastern Mediterranean region
}

\author{
Gideon Hartman • Avinoam Danin
}

Received: 19 April 2009/ Accepted: 3 November 2009/Published online: 3 December 2009

(C) The Author(s) 2009. This article is published with open access at Springerlink.com

\begin{abstract}
Plant $\mathrm{C}$ and $\mathrm{N}$ isotope values often correlate with rainfall on global and regional scales. This study examines the relationship between plant isotopic values and rainfall in the Eastern Mediterranean region. The results indicate significant correlations between both $\mathrm{C}$ and $\mathrm{N}$ isotope values and rainfall in $\mathrm{C}_{3}$ plant communities. This significant relationship is maintained when plant communities are divided by plant life forms. Furthermore, a seasonal increase in $\mathrm{C}$ isotope values is observed during the dry season while $\mathrm{N}$ isotope values remain stable across the wet and dry seasons. Finally, the isotopic pattern in plants originating from desert environments differs from those from Mediterranean environments because some desert plants obtain most of their water from secondary sources, namely water channeled by local topographic features rather than direct rainfall. From these results it can be concluded that water availability is the primary factor controlling $\mathrm{C}$ and $\mathrm{N}$ isotope variability in plant communities in the Eastern Mediterranean.
\end{abstract}

Communicated by Hermann Heilmeier.

Electronic supplementary material The online version of this article (doi:10.1007/s00442-009-1514-7) contains supplementary material, which is available to authorized users.

\section{G. Hartman $(\bowtie)$}

Department of Human Evolution, Max Planck Institute for Evolutionary Anthropology, Deutscher Platz 6, 04103 Leipzig, Germany

e-mail: gideon_hartman@eva.mpg.de

\section{A. Danin}

Department of Evolution, Systematics, and Ecology,

The Hebrew University of Jerusalem, 91904 Jerusalem, Israel
Keywords Carbon isotopic composition · Nitrogen isotopic composition · Rainfall · Plant community $\cdot$ Seasonality

\section{Introduction}

Water availability, measured as rainfall, is argued to be the most influential factor affecting the $\mathrm{C}\left(\delta^{13} \mathrm{C}\right)$ and $\mathrm{N}$ isotopic composition $\left(\delta^{15} \mathrm{~N}\right)$ of plants in semi-arid and arid environments (Stewart et al. 1995; Handley et al. 1999; Amundson et al. 2003; Swap et al. 2004). The relationship between rainfall and the isotopic composition of plants has been demonstrated in many regions, but has not been investigated in the Eastern Mediterranean. This paper tests whether a similar relationship exists in this region. Although a dominant factor, rainfall is not the only variable that may affect water availability (for example see Schulze et al. 1996). In particular, topography and seasonality may also affect the relationship between rainfall and plant isotopic composition (Ehleringer and Cooper 1988; Smedley et al. 1991). The Eastern Mediterranean climate is characterized by a strongly seasonal pattern of rainfall, with rain falling nearly exclusively in the cool winter season and steep rainfall gradients that range from over $1,000 \mathrm{~mm} /$ year to below $100 \mathrm{~mm} /$ year within a small geographic area (Goldreich 2003). Likewise, topography influences water availability by impacting the water drainage and retention capacities of local soils. The effect of topography on isotopic values can be particularly pronounced in arid regions (Ehleringer and Cooper 1988; Farrell et al. 1996).

This study documents the relationship between water availability and the $\mathrm{C}$ and $\mathrm{N}$ isotopic values of plants on a community level in the Eastern Mediterranean and evaluates the effect of seasonality and topography on this 
relationship. The relationship between rainfall and plant isotopes is established through intensive sampling of plants across north-south and east-west rainfall gradients in the Eastern Mediterranean. The effect of seasonality on water availability is investigated by collecting data on both wet (October-April) and dry (May-September) season plants, while the impact of topographic setting is investigated by comparing the isotopic signatures of plants growing in elevated (exposed ridges) versus depressed (dry washes) settings in arid regions.

\section{Theoretical background}

\section{$C$ isotope discrimination and water use efficiency}

The following equation estimates the $\mathrm{C}$ isotope discrimination $\left({ }^{13} \Delta\right)$ in $C_{3}$ plants (Farquhar et al. 1989):

${ }^{13} \Delta=a \frac{P_{\mathrm{a}}-P_{\mathrm{i}}}{P_{\mathrm{a}}}+b \frac{P_{\mathrm{i}}}{P_{\mathrm{a}}}=a+(b-a) \frac{P_{\mathrm{i}}}{P_{\mathrm{a}}}$

Where the constant $a(=4.4 \%$ ) is fractionation occurring during the diffusion of $\mathrm{CO}_{2}$ through the stomata (Craig 1953), and the constant $b(=27 \%$ ) is the fractionation associated with $\mathrm{CO}_{2}$ fixation by ribulose bisphosphate carboxylase/oxygenase (RuBisCO; Farquhar and Richards 1984). $P_{\mathrm{a}}$ refers to air and $P_{\mathrm{i}}$ to intracellular partial $\mathrm{CO}_{2}$ pressure. Reduced stomatal conductivity caused by drought stress leads to a decrease in the $P_{\mathrm{i}} / P_{\mathrm{a}}$ ratio and results in a decrease in ${ }^{13} \Delta$ (Farquhar et al. 1982). The $\delta^{13} \mathrm{C}$ values of plants $\left(\delta^{13} \mathrm{C}_{\mathrm{p}}\right)$ can be directly related to ${ }^{13} \Delta$ though this requires an a priori assumption about the $\delta^{13} \mathrm{C}$ values of atmospheric $\mathrm{CO}_{2}\left(\delta^{13} \mathrm{C}_{\mathrm{a}}\right)$ :

$\delta^{13} \mathrm{C}_{\mathrm{p}}(\%)=\frac{\delta^{13} \mathrm{C}_{\mathrm{a}}-{ }^{13} \Delta}{1+{ }^{13} \Delta}$

The present-day $\delta^{13} \mathrm{C}_{\mathrm{a}}$ value is $\sim-8 \%$, yet this value may vary seasonally on local and global scales, most importantly as a consequence of fossil fuel combustion (Keeling et al. 2005).

Given the above, $\mathrm{C}_{3}$ plants growing under conditions of water stress are expected to have elevated $\delta^{13} \mathrm{C}$ values compared to plants growing under optimal water conditions (Farquhar and Sharkey 1982). A number of studies have found a negative correlation between mean annual rainfall and the $\delta^{13} \mathrm{C}$ of $\mathrm{C}_{3}$ plants (Stewart et al. 1995; Swap et al. 2004). Studies undertaken in seasonal, semiarid environments also report higher $\delta^{13} \mathrm{C}$ values in grassland plant species and pine needles collected in the dry versus wet season (Smedley et al. 1991; Klein et al. 2005). Despite the strong association between rainfall and the $\delta^{13} \mathrm{C}$ values of $\mathrm{C}_{3}$ plants, other factors including genetic, structural, and functional plant adaptations and soil characteristics can also change the water use efficiency
(WUE; the ratio of water loss to biomass gained) and thus may influence the relationship between rainfall and the $\delta^{13} \mathrm{C}$ values of $\mathrm{C}_{3}$ plants (Ehleringer and Cooper 1988; Comstock and Ehleringer 1992; Schulze et al. 1996, 2006; Dawson et al. 2002 and references therein). Given the potential confounding effect of these variables, the relationship between rainfall and $\delta^{13} \mathrm{C}$ values of $\mathrm{C}_{3}$ plants must first be established. Here, it is hypothesized that the $\delta^{13} \mathrm{C}$ values of $\mathrm{C}_{3}$ plant communities will be significantly negatively correlated with rainfall in the Eastern Mediterranean region. Additionally, the $\delta^{13} \mathrm{C}$ values of $\mathrm{C}_{3}$ plants growing during the hot and dry season are expected to be significantly higher than those of plants growing during the cool and wet season. In contrast to $\mathrm{C}_{3}$ plants, the isotopic composition of $\mathrm{C}_{4}$ plants is not expected to be affected by water stress (Farquhar et al. 1982; Farquhar 1983).

\section{$N$ isotope distribution in plants and its relation to water availability}

A negative correlation has also been reported between the $\mathrm{N}$ isotopic values of plants and bulk soils and rainfall (Heaton 1987; Austin and Vitousek 1998; Handley et al. 1999; Amundson et al. 2003; Swap et al. 2004). The association between rainfall and plant $\delta^{15} \mathrm{~N}$ values is not straightforward-while plants fix $\mathrm{C}$ directly from the atmosphere, they obtain $\mathrm{N}$ from the soil or through a symbiotic relationship with $\mathrm{N}$-fixing microorganisms. Many climate-linked factors such as the activity of soil microorganisms, variability in soil $\mathrm{N}$ sources (i.e., $\mathrm{NO}_{3}{ }^{-}$, $\mathrm{NH}_{4}{ }^{+}$), and plant metabolism also influence plant $\delta^{15} \mathrm{~N}$ values (Handley and Raven 1992; Högberg 1997). Handley et al. (1999) suggested that the observed negative correlation between plant $\delta^{15} \mathrm{~N}$ values and rainfall is a product of water availability and soil $\mathrm{N}$ sources during plant growth. An increase in the $\delta^{15} \mathrm{~N}$ values of both soils and plants under conditions of decreasing rainfall has been attributed to more open $\mathrm{N}$ cycling in ecosystems with higher $\mathrm{N}$ loss relative to turnover (Austin and Vitousek 1998). Plant physiology has also been shown to be at least partly responsible for higher $\delta^{15} \mathrm{~N}$ values in water-stressed grasses (Lopes and Araus 2006). Despite gaps in current understanding of the mechanism, it is hypothesized that there will be a negative relationship between the $\delta^{15} \mathrm{~N}$ values of plant communities and rainfall in the Eastern Mediterranean. It is also hypothesized that the $\delta^{15} \mathrm{~N}$ values of $\mathrm{C}_{3}$ plants that grow during the dry season will be significantly higher than those that grow during the wet season.

An independent measure of water availability during plant growth, the degree of concentration of $\mathrm{N}$ in $\mathrm{C}_{3}$ plant leaves (measured as the $\mathrm{C} / \mathrm{N}$ ratio), is also used here. Plants growing in regions with low annual rainfall improve light 
use efficiency by increasing leaf $\mathrm{N}$ concentration relative to plants growing in wetter regions (Field et al. 1983; Cunningham et al. 1999).

\section{Materials and methods}

\section{Plant collection}

Plant samples ( $n=1,400$; for a complete list of plant species, season of collection, life form, and other attributes for each site see Appendix A in ESM) were collected from 27 sites along the major north-south and west-east rainfall gradients in Israel and the Palestinian Authority ranging from 1,000 to below $100 \mathrm{~mm}$ rain/year (Table 1; Fig. 1). Plants were collected in undisturbed and protected areas under a permit granted by the Israel Nature and National Parks Protection Authority to minimize the biasing effect of anthropogenic activity. For the same reason, plant collection was avoided in river beds except arid environments (see below). The exact location of each collection site was recorded using a GPS device; the coordinates were later used to extract rainfall data from the Hebrew University GIS center databases. Three plants from each of ca. 15 dominant species located within a $10-\mathrm{m}$ radius of a randomly assigned sampling point were collected at every site. Sun-exposed leaves of shrubs and trees were collected from the outer surface of the crown at ca. $1.5 \mathrm{~m}$ above the ground surface.

The sampling locations along the north-south and westeast rainfall gradients were chosen independently in consultation with rainfall maps at roughly $100-\mathrm{mm}$ per year increments. Higher isotopic variability was expected in the transitional areas between Mediterranean and desert environments (200-75 mm/year) and thus sampling stations were added at frequencies $<100 \mathrm{~mm} /$ year. The plants were collected in two episodes representing the peak of the wet and dry season. The dry season collection took place in July-August 2006 and the wet season collection took place in March 2007. Recently expanded leaves were collected during the wet season, and also in the dry season when available. While most of the lignified species collected in this study are evergreen, winter deciduous tree species $(n=1)$ and drought deciduous shrub and tree species ( $n=6$ ) were also collected. Many of the dwarf shrub species replace short-lived leaves typical of the wet season with long-lived leaves in the dry season (see Appendix A in ESM for the longevity of leaf and photosynthetic stems of the lignified species sampled here).

To test whether topographic differences affect water availability and the $\delta^{13} \mathrm{C}$ and $\delta^{15} \mathrm{~N}$ values of plants in arid environments, five wet season desert sites were sampled. Plants were collected in each of these sites from dry wash beds (wadis) and adjacent exposed ridges. Data collected from exposed ridges or dry washes at other arid sites were also included in the sample. Since desert plants that grow in fissures on smooth dolomite rock outcrops (DWD) also trap water, plants collected from these locations were also included with the dry wash sites (see Table 1 for DWD sites; Danin 1983). The eastern dry wash desert sites in this study are fed by locally drained rainwater rather than spring water or major washes that might be contaminated by $\mathrm{N}$ from fertilizers and sewage. The southern dry wash desert sites drain water from the higher Negev hills which do not support agriculture or major human settlements (Bedard-Haughn et al. 2003; Segal-Rozenhaimer et al. 2004; for site locations see Fig. 1).

\section{Plant processing}

The plants were identified to the species level in the field and were then dry-pressed and frozen and shipped to Harvard University for analysis. In the laboratory plant leaves and other non-lignified parts were ground in liquid nitrogen using a mortar and pestle. The plant species $(n=241)$ were then collapsed into the following major Raunkiær life forms: annuals (therophytes $n=104$ ), forbs (hemicryptophytes $n=36)$, geophytes $(n=21)$, dwarf shrubs (chamaephytes $n=56$ ), shrubs and trees (phanerophytes $n=24$; Danin and Orshan 1990). Trees and shrubs were collapsed into a single group since semi-arid Mediterranean trees often branch close to the ground making the two groups functionally and in many cases taxonomically similar. Geophytes were collected only in the wet season since in most cases their above-ground growth is limited. Dry and green plant specimens collected in the dry season of 2006 were separated during processing and analysis. This strategy was designed to illuminate the isotopic differences between wet and dry season plants - specifically, what part of the dry season isotopic pattern is derived from growth that reached completion during the previous rainy season (represented by dry plants), and what part also included growth under dry season conditions (for green and dry plant list see Appendix A in ESM). Other than a few dwarf shrubs $(n=3)$, all of the dry plant species collected in the dry season $(n=70)$ were annuals or forbs. An equal contribution of the different species that comprise each functional group was ensured by weighing standardized amounts $(20 \mathrm{mg})$ of dried plant material from each species into a reaction tube prior to homogenization. The plant mixtures were homogenized using a micro beadbeater and the product was weighed $(2 \mathrm{mg})$ in duplicate into tin boats and shipped to Boston University Stable Isotope Laboratory for analysis. (For a complete list of collected plant species see Appendix A in ESM.) 


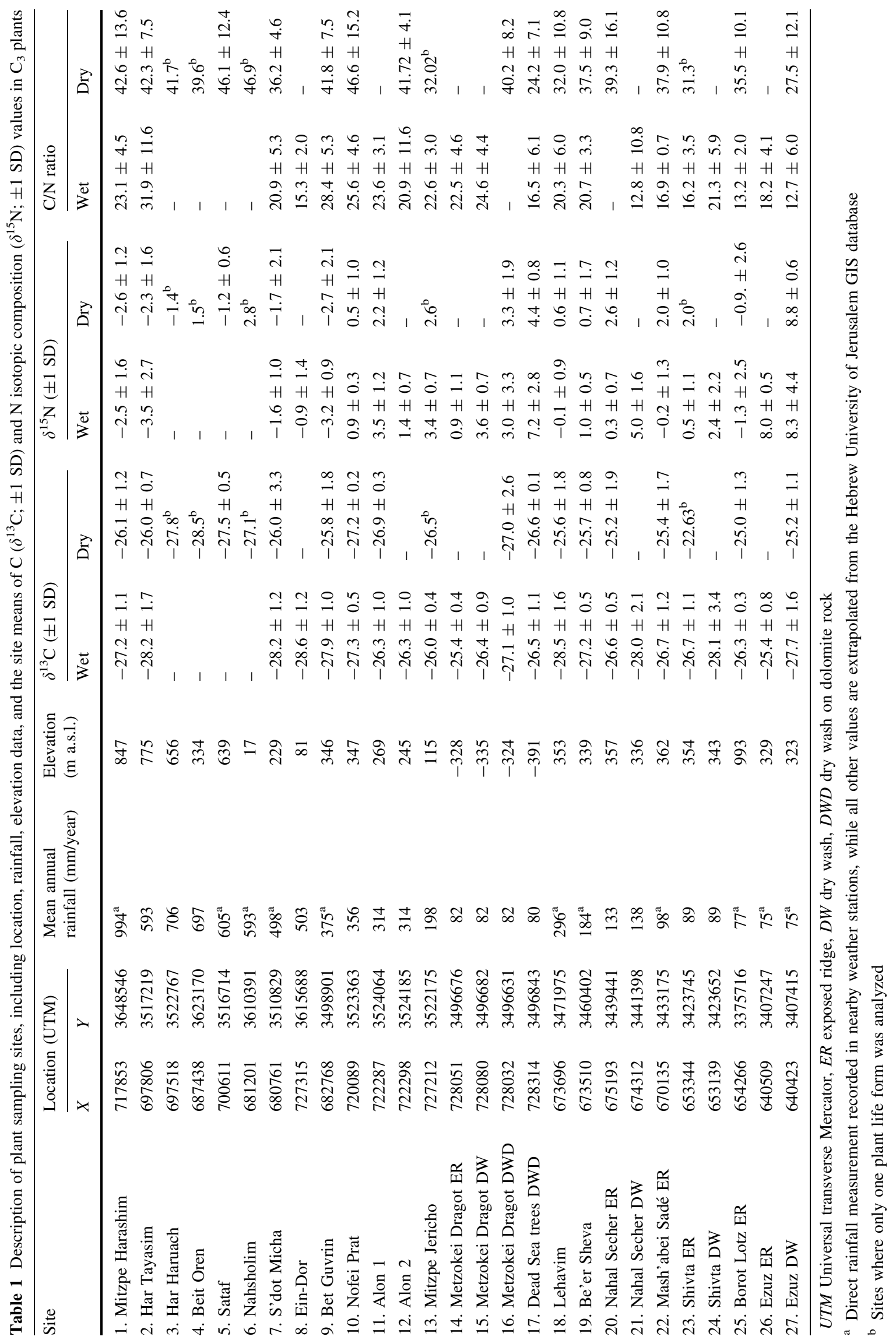




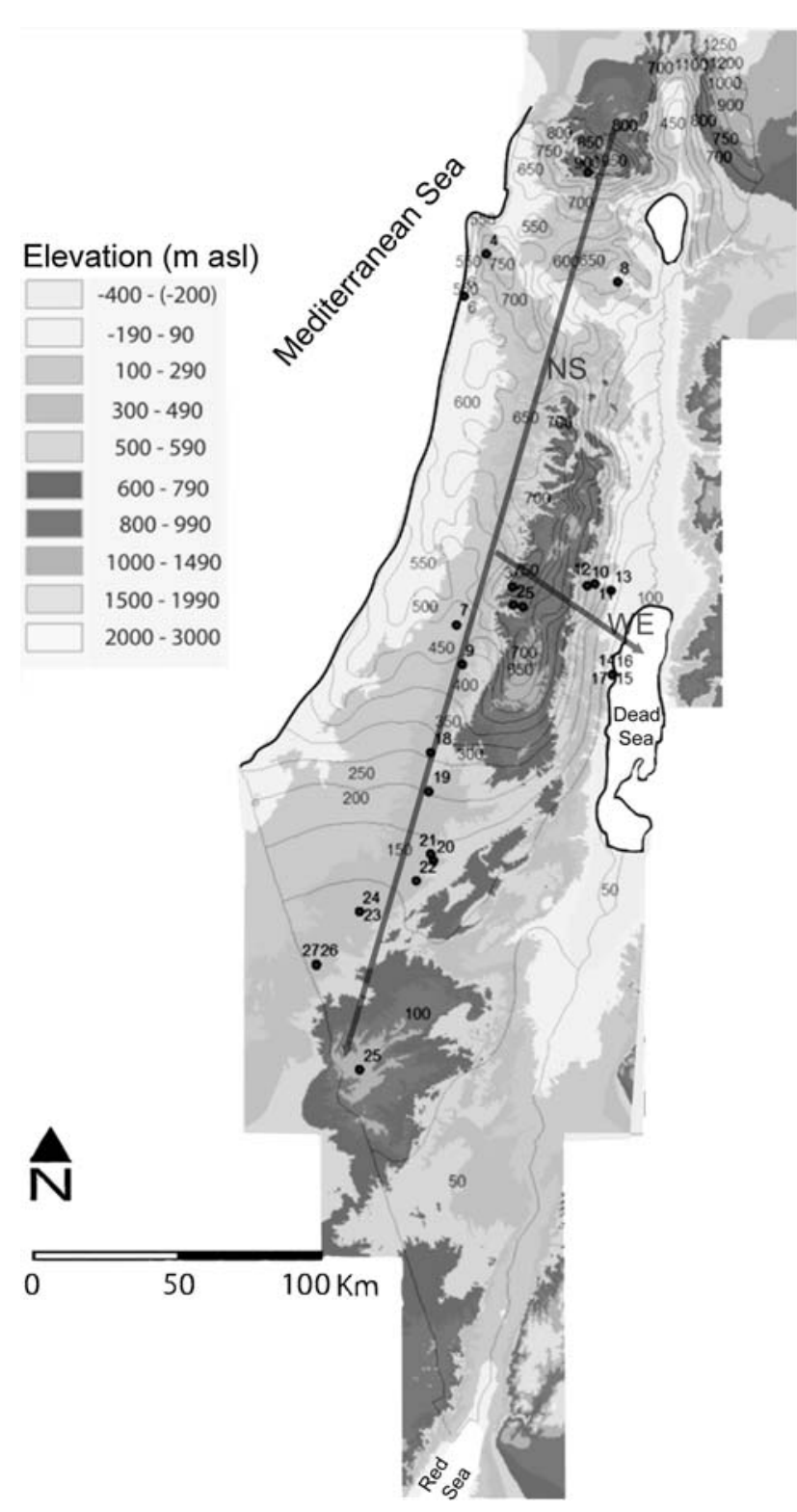

Fig. 1 Relief map indicating plant collection sites in the Eastern Mediterranean region. Plant collection sites are numbered in black (see Table 1 for site description). Rainfall data are depicted by isohyets (values in gray; mean annual rainfall; mm/year). Gray arrows represent the major rainfall gradients: north-south $(N S)$ and west-east $(W E)$

Isotopic and $\mathrm{C} / \mathrm{N}$ ratio analyses

Plant samples were analyzed using an automated continuous-flow isotope ratio mass spectrometer (Preston and Owens 1983). The samples were combusted in a EuroVector Euro elemental analyzer. The combustion gases $\left(\mathrm{N}_{2}\right.$ and $\mathrm{CO}_{2}$ ) were separated on a GC column, passed through a GVI diluter (GV Instruments) and reference gas box, and introduced into the GVI IsoPrime isotope ratio mass spectrometer. Water was removed using a magnesium perchlorate water trap. Ratios of ${ }^{13} \mathrm{C} /{ }^{12} \mathrm{C}$ and ${ }^{15} \mathrm{~N} /{ }^{14} \mathrm{~N}$ were expressed as the relative per mil (\%o) difference between the samples and international standards [Vienna Pee Dee belemnite (V-PDB) carbonate and $\mathrm{N}_{2}$ in air] where:

$\delta X=\left(R_{\text {sample }} / R_{\text {standard }}-1\right) \times 1,000(\%)$

where $X={ }^{13} \mathrm{C}$ or ${ }^{15} \mathrm{~N}$ and $R={ }^{13} \mathrm{C} /{ }^{12} \mathrm{C}$ or ${ }^{15} \mathrm{~N} /{ }^{14} \mathrm{~N}$

The sample isotope ratio is compared to a secondary gas standard with an isotope ratio that was calibrated to international standards. For ${ }^{13} \mathrm{C}_{\mathrm{V}-\mathrm{PDB}}$ the gas was calibrated against NBS 20 (Solnhofen limestone, $-1.05 \pm 0.02 \%$ ). For ${ }^{15} \mathrm{~N}_{\text {air }}$ the gas was calibrated against atmospheric $\mathrm{N}_{2}$ and IAEA standards $\mathrm{N}-1, \mathrm{~N}-2\left[\left(\mathrm{NH}_{4}\right)_{2} \mathrm{SO}_{4}, 0.4 \pm 0.2 \%\right.$ and $20.3 \pm 0.2 \%$ respectively], and $\mathrm{NO}_{3}^{-}\left(\mathrm{KNO}_{3}\right.$, $4.7 \pm 0.2 \%$ ). All international standards were obtained from the National Bureau of Standards in Gaithersburg, Maryland. Continuous flow also reported mass $\% \mathrm{C}$ and mass $\% \mathrm{~N}$ data from which the $\mathrm{C} / \mathrm{N}$ ratio was calculated. The $\% \mathrm{C}$ and $\% \mathrm{~N}$ values were calibrated against known quantities of the peptone and glycine standards.

Rainfall and climatic data acquisition

Mean rainfall data from weather stations located within $10 \mathrm{~km}$ of plant collection sites were obtained from the Israeli Meteorological Service for the years 1961-1990. Additional information from weather stations was obtained from the meteorological service of the Israeli Ministry of Agriculture (http://www.moag.gov.il/csv/index.html). Rainfall data for plant collection sites that were not located in the immediate proximity of weather stations were taken from the Hebrew University of Jerusalem GIS center database for the same years. The rainfall data were extrapolated from weather stations using the inverse distance weight algorithm method. Rainfall amounts can vary greatly from year to year in arid regions. Since the dry season plant data reflect growth in the 2005/2006 wet season while the wet season data derive from 2006/2007, the total amount of rainfall for the 2 years was compared for 13 sites. Data for this analysis were taken from the Israel Central Bureau of Statistics (ICBS) (http://www. cbs.gov.il/reader/shnaton/templ_shnaton.html?num_tab= st01_04\&CYear=2007; http://www.cbs.gov.il/reader/shnaton/ templ_shnaton.html?num_tab=st01_04\&CYear=2008). The difference in rainfall for the 2005/2006 and 2006/2007 wet seasons was insignificant (paired $t$ test, $P=0.509$ ), and can therefore be treated as representative of a single year.

The high resolution rainfall data available for this study from the GIS database cover a range of 30 years (19611990). Rainfall values averaging the 4 years leading up to and during the study period (2003-2006) would have been preferred, since they best represent water availability during the growth of the sampled plants, but these data are not currently available in GIS format. It was thus important to 
test whether the long- and short-term rainfall data sets are comparable. The same ICBS dataset of 13 sites used in the previous comparison was used to test the question. The amount of rainfall measured between 2003/2004 and 2006/ 2007 was significantly lower than the mean annual rainfall measured between 1961 and 1990 (paired $t$-test, $P=0.014$ ), but rainfall from the two groups was also highly correlated ( $\left.y=0.94 x-9.5, R^{2}=0.95, P<0.0001\right)$. The intercept of the regression line formed between the recent years' and long-term rainfall data sets indicate a small yet consistent difference of approximately $10 \mathrm{~mm} /$ year. While the mean annual rainfall in recent years was smaller than the mean value for the years 1961-1990, the distribution of rainfall appears to be uniform across climatic regions. Next, the effect of a 10-mm difference in rainfall on the regression equations presented in the "Results" section (see below) was investigated. The effect of a $10-\mathrm{mm}$ decrease in the mean annual rainfall on the predicted plant isotope values is approximately $0.01-0.1 \%$ for $\delta^{13} \mathrm{C}$ and $0.04-0.36 \%$ for $\delta^{15} \mathrm{~N}$. The low end of the range represents the wet regions (1,000 mm/year) while the high end of the range represents more arid regions (100 mm/year). These differences are very small and fall within the $95 \%$ confidence intervals for the expected isotopic values presented in the "Results" section. The use of the 30-year-averaged data is thus not expected to have had any significant effect on the results presented here, and they are preferred for their substantially more robust coverage of the study area.
Statistical analysis

The relationship between rainfall and the $\delta^{13} \mathrm{C}$ and $\delta^{15} \mathrm{~N}$ values of plants was examined using linear regression analysis. The logistic trend-line formed between mean annual rainfall and plant isotopic composition was corrected using the natural $\log (\ln )$ of the rainfall data; $95 \%$ confidence intervals were calculated for the resulting trendlines. Paired $t$-tests were used to detect seasonal and topographic differences in plant $\delta^{13} \mathrm{C}$ and $\delta^{15} \mathrm{~N}$ data originating from the same site. Seasonal and topographic differences among sites were investigated using a $t$ test. Non-normally distributed data were examined using a Mann-Whitney rank sum test. Seasonal differences between regression slopes and intercepts (elevations) were analyzed using a $t$ test (Zar 1999). The regression lines of multiple plant life forms were compared following the analysis of covariance procedure detailed in Zar (1999).

\section{Results}

Correlation between rainfall and the isotopic composition of plants

Both the mean $\delta^{13} \mathrm{C}$ and $\delta^{15} \mathrm{~N}$ values of $\mathrm{C}_{3}$ plants were negatively correlated with rainfall (Table 2). The omission of arid dry wash sites from the $\delta^{13} \mathrm{C}$ analysis and exposed

Table 2 The linear relationship between mean $\mathrm{C}\left(\delta^{13} \mathrm{C}\right)$ and $\mathrm{N}$ isotopic composition $\left(\delta^{15} \mathrm{~N}\right)$ values and the $\mathrm{C} / \mathrm{N}$ ratio from $\mathrm{C}_{3}$ plant sites and mean annual rainfall

\begin{tabular}{|c|c|c|c|c|c|}
\hline Rainfall (Ln mm/year) & $\beta$ & $\alpha$ & $n$ & $R^{2}$ & $P$ \\
\hline \multicolumn{6}{|l|}{$\delta^{13} \mathrm{C}^{\mathrm{a}}$} \\
\hline $\mathrm{W}$ & $-0.82(-1.17)$ & $-22.95(-20.76)$ & $23(17)$ & $0.41(0.67)$ & $<0.05(<0.001)$ \\
\hline $\mathrm{D}$ & $-0.55(-0.78)$ & $-22.88(-21.74)$ & $18(15)$ & $0.18(0.44)$ & $0.086(<\mathbf{0 . 0 1})$ \\
\hline $\mathrm{Dg}$ & $-0.96(-1.73)$ & $-20.75(-15.97)$ & $17(14)$ & $0.32(0.79)$ & $<0.05(<0.001)$ \\
\hline Dd & $-0.97(-1.22)$ & $-21.74(-20.19)$ & $17(16)$ & $0.45(0.61)$ & $<0.01(<0.001)$ \\
\hline A & $-0.58(-0.96)$ & $-23.59(-21.21)$ & $39(30)$ & $0.14(0.33)$ & $<0.05(<0.001)$ \\
\hline \multicolumn{6}{|l|}{$\delta^{15} \mathrm{~N}^{\mathrm{b}}$} \\
\hline $\mathrm{W}$ & $-2.60(-3.47)$ & $15.09(20.43)$ & $23(17)$ & $0.39(0.70)$ & $0.001(<0.001)$ \\
\hline $\mathrm{D}$ & $-2.69(-3.32)$ & $15.38(19.71)$ & $16(14)$ & $0.58(0.76)$ & $<0.001(<0.001)$ \\
\hline A & $-2.59(-3.45)$ & $14.96(20.69)$ & $39(28)$ & $0.46(0.76)$ & $<0.001(<0.001)$ \\
\hline \multicolumn{6}{|l|}{$\mathrm{C} / \mathrm{N}^{\mathrm{b}}$} \\
\hline W & $3.19(2.99)$ & $3.73(4.84)$ & $21(15)$ & $0.28(0.21)$ & $<\mathbf{0 . 0 5}(0.087)$ \\
\hline $\mathrm{D}$ & $4.67(5.65)$ & $12.32(5.94)$ & $20(17)$ & $0.43(0.50)$ & $<0.01(<0.01)$ \\
\hline
\end{tabular}

$W$ Wet season; $D$ dry season; $D g$ dry season green plants; $D d$ dry season dried plants; $A$ annual, combined wet and dry period; $n$ number of sites; $\beta$ slope; $\alpha$ intercept

$P$ values $<0.05$ are marked in bold

${ }^{\text {a }}$ Dry wash desert sites are excluded from the $\delta^{13} \mathrm{C}$ regression analysis, results are shown in parentheses

${ }^{\mathrm{b}}$ Exposed ridge sites are excluded from the $\delta^{15} \mathrm{~N}$ and $\mathrm{C} / \mathrm{N}$ analysis, results are shown in parentheses 
Fig. 2 Correlation between mean annual rainfall, mean site isotopic composition, and $\mathrm{C} / \mathrm{N}$ ratio of $\mathrm{C}_{3}$ plants in the wet and dry seasons. Plants collected in the 2006 dry season indicated by triangles, dashed regression lines; plants collected in the 2006/2007 wet season indicated by squares, solid regression lines; $95 \%$ confidence intervals of the regression lines indicated by dotted lines. a Mean site $\mathrm{C}$ isotopic composition $\left(\delta^{13} \mathrm{C}\right)$ values versus rainfall; closed symbols sites with $>150 \mathrm{~mm}$ rainfall/year, gray symbols exposed ridge sites, open symbols dry wash sites (not included in the regression analysis). b Mean site $\mathrm{N}$ isotopic composition $\left(\delta^{15} \mathrm{~N}\right)$ versus rainfall; closed symbols sites with $>150 \mathrm{~mm}$ rainfall/year, open symbols dry wash sites, gray symbols exposed ridge sites (not included in regression analysis). Note that the dry and wet season regression lines overlap exactly. c $\mathrm{C} / \mathrm{N}$ ratio versus rainfall for all sites. For statistics see Table 2

ridge sites from the $\delta^{15} \mathrm{~N}$ analysis (see below) resulted in higher correlations (Table 2).

There are significant correlations between the $\delta^{15} \mathrm{~N}$ values of each of the four life forms and rainfall (annuals $n=32, R^{2}=0.38, P<0.001$; forbs $n=28, R^{2}=0.34$, $P<0.001$; dwarf shrubs $n=32, R^{2}=0.54, P<0.001$; shrubs and trees $\left.n=19, R^{2}=0.77, P<0.001\right)$. The correlation between rainfall and the $\delta^{13} \mathrm{C}$ values of each of the plant life forms, however, was significant only for annuals and dwarf shrubs; and only when desert dry wash sites were excluded from the analysis (annuals $n=27$, $R^{2}=0.40, \quad P<0.001 ; \quad$ forbs $n=24, \quad R^{2}=0.13$, $P=0.090$; dwarf shrubs $n=24, R^{2}=0.33, P=0.004$; shrubs and trees $n=19, R^{2}=0.30, P=0.055$; but see seasonal data below).

No relationship was found between the $\delta^{13} \mathrm{C}$ values of $\mathrm{C}_{4}$ plants and rainfall $\left(n=24, R^{2}=0.0007, P=0.905\right.$; Appendix B in ESM). The $\delta^{15} \mathrm{~N}$ values for $\mathrm{C}_{4}$ plants were consistently higher than the values measured for $\mathrm{C}_{3}$ plants from the same site $(+2.0 \%$ difference; paired $t$ test, $P<0.001$; Appendix $\mathrm{C}$ in ESM). Since most of the $\mathrm{C}_{4}$ plant species in this study are dwarf shrubs (chenopods) they were also compared to $\mathrm{C}_{3}$ dwarf shrubs from the same sites with similar results $(+2.1 \%$ difference; paired $t$ test, $P<0.001)$. The regression slopes of the $\delta^{15} \mathrm{~N}$ of $\mathrm{C}_{3}$ plants on rainfall and the $\delta^{15} \mathrm{~N}$ of $\mathrm{C}_{4}$ plants on rainfall were statistically similar $(P=0.936)$.

Seasonal variability in isotopic composition and $\mathrm{C} / \mathrm{N}$ ratio of $\mathrm{C}_{3}$ plants

The mean $\delta^{13} \mathrm{C}$ values of $\mathrm{C}_{3}$ plants collected in both the wet and dry seasons were negatively correlated with rainfall (Table 2). The regression slopes of rainfall and the $\delta^{13} \mathrm{C}$ values of $\mathrm{C}_{3}$ plants collected in the wet versus dry season were significantly different $(P<0.05)$, with the dry season site means exceeding wet season site means (paired $t$ test, $P<0.001$; Fig. $2 \mathrm{a})$. When green and dry plants collected in the dry season were separated, the slope and intercept of the regression line formed between the $\delta^{13} \mathrm{C}$
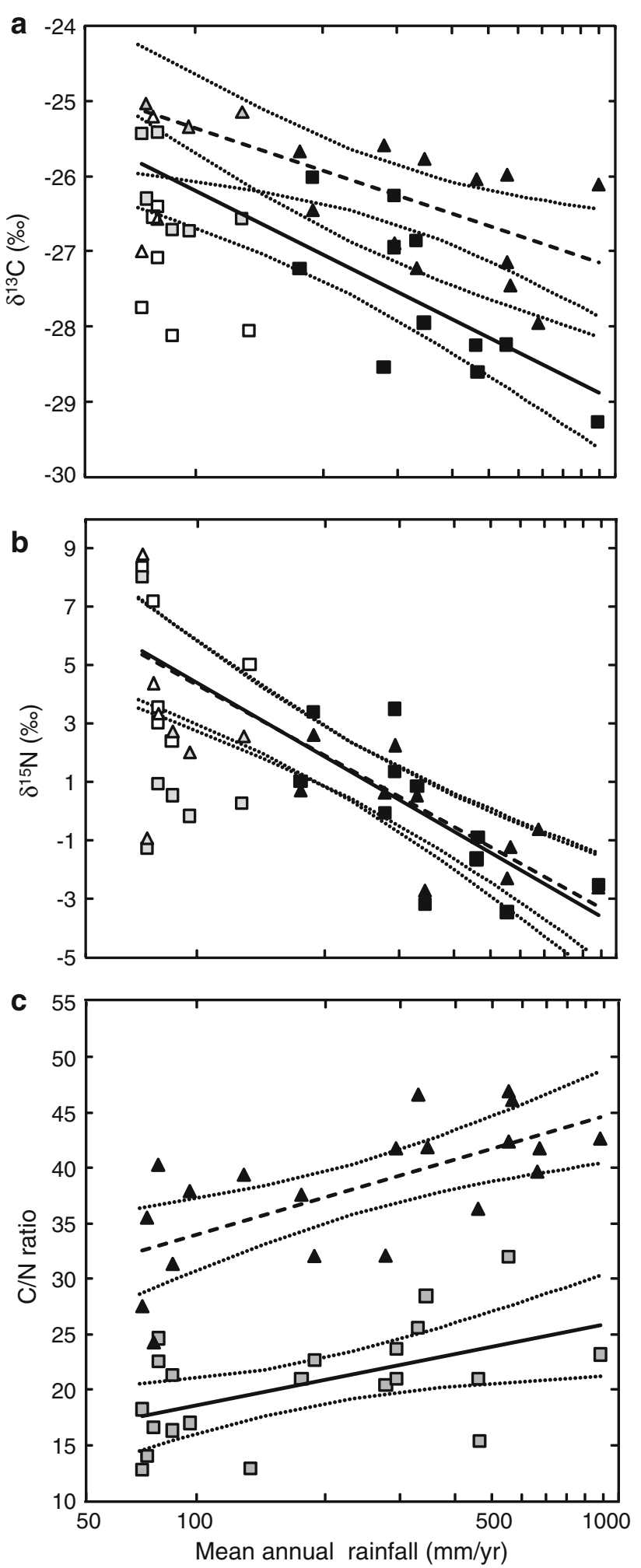

values of dry plants and rainfall were similar to those for the wet season sites (slope $P=0.99$; intercept $P=0.22$; Fig. 3a). The slope and intercept of dry season green and dry plants were significantly different (slope $P<0.05$; 
Fig. 3 Contribution of dry and green plants to the relationship between $\delta^{13} \mathrm{C}$ values of dry season plants and rainfall. a Dry season, $\mathrm{C}$ isotope site means of dried plants indicated by triangles, gray regression line; wet season site means indicated by squares, solid regression line with $95 \%$ confidence intervals indicate by dotted lines (dry wash sites not included in regression analysis). b Dry season site mean regression line indicated by bold solid line is compared to the regression of green (open triangles, hatched regression line) and dry plants (closed triangles, dotted regression line) with 95\% confidence intervals (dry wash sites not included in regression analysis). c Correlation between green/dry plants ratio per site (number of species from each group) during dry season and mean annual rainfall

intercept $P<0.01$; Fig. 3b), with the $\delta^{13} \mathrm{C}$ values of green plants being consistently higher than those of dry plants. The green to dry plant ratio in plants collected in the dry season sites shows a positive correlation with rainfall. Green plants thus comprise a larger portion of the total plants collected in wetter regions compared to drier regions (Fig. 3c). The latter observation demonstrates that the dry season regression line slope and intercept that include all plants are driven by green plants in wetter environments while dry plants are more influential in drier environments.

Higher $\delta^{13} \mathrm{C}$ values were also found in dry than in wet season $\mathrm{C}_{3}$ plants when they were separated into life forms (paired $t$ test, annuals $P<0.05$; forbs $P<0.01$; dwarf shrubs $P<0.01$; shrubs and trees $P<0.001$; Fig. 4). The intercepts of the regression lines of rainfall on the $\delta^{13} \mathrm{C}$ values of wet versus dry season plants were also significantly different when each of the four life forms was analyzed independently (Table 3). The regression slopes, however, do not show any seasonal difference (Table 3). In summary, the seasonal $\delta^{13} \mathrm{C}$ data indicate two primary trends. First, plant $\delta^{13} \mathrm{C}$ values increase as rainfall decreases in both the wet and dry seasons and second, $\delta^{13} \mathrm{C}$ values are significantly higher in the dry than the wet season.

A comparison of the regression slopes and intercepts of rainfall on the $\delta^{13} \mathrm{C}$ values of herbaceous life forms (annuals and forbs) collected in the wet versus dry season suggests that seasonal differences in $\delta^{13} \mathrm{C}$ values are more pronounced in sites with high annual rainfall (Table 3; Fig. 4). This pattern does not occur in the lignified plant groups (e.g., dwarf shrubs, shrubs and trees; Fig. 4). When the four plant life forms were compared, there was no significant difference between the regression slopes of plant $\delta^{13} \mathrm{C}$ values on rainfall in the wet and dry seasons, but there were significant differences in the intercepts of the wet season plants from the different life forms (wet season, slopes $P=0.223$, intercepts $P<0.05$; dry season, slopes $P=0.492$, intercepts $P=0.223$ ). The plant life forms cluster into two major groups based on their dry season
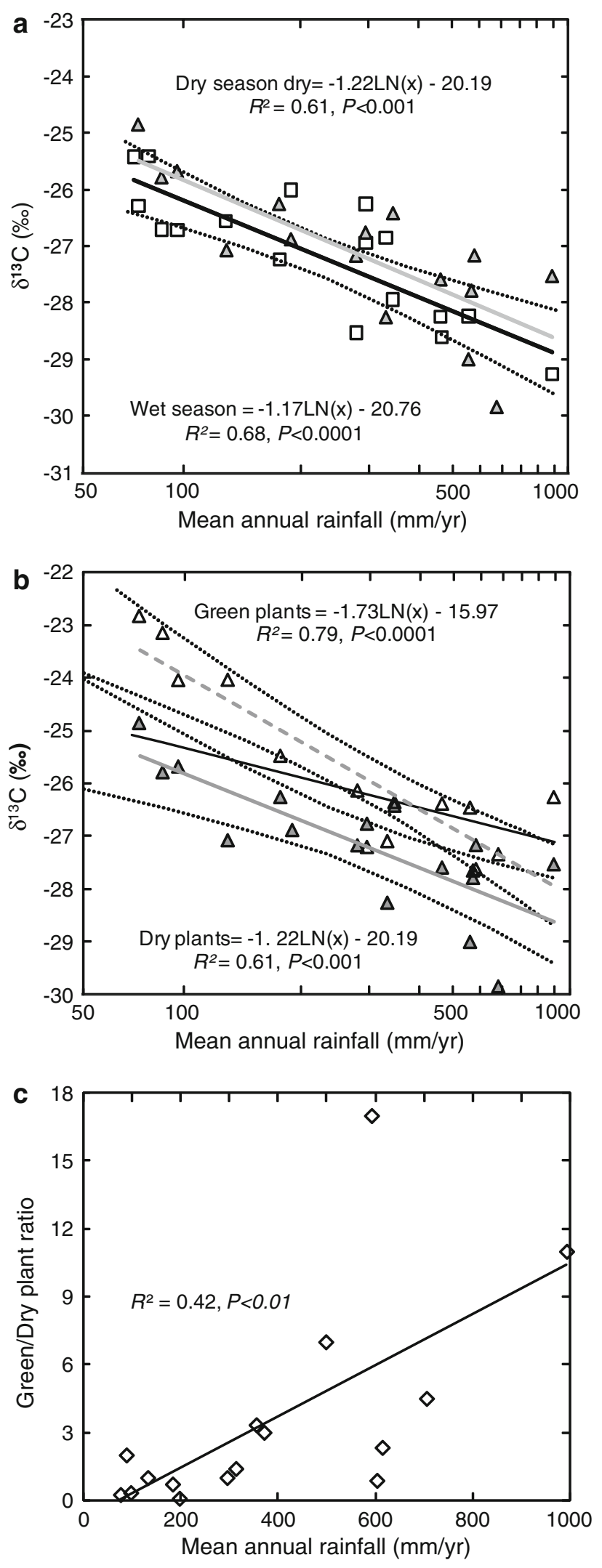
Fig. 4 Relationship between mean $\delta^{13} \mathrm{C}$ and $\delta^{15} \mathrm{~N}$ values of plants according to life form and mean annual rainfall. Plant $\delta^{13} \mathrm{C}$ regression lines exclude desert dry wash sites and $\delta^{15} \mathrm{~N}$ regression lines exclude desert exposed ridge sites. Wet season plant sites are indicated by squares, solid regression lines; dry season plant sites are indicated by triangles, dashed regression lines. Open symbols depict dry wash sites and gray symbols depict exposed ridge sites. a annuals, b forbs, c geophytes (wet season data only), $\mathbf{d}$ dwarf shrubs, and $\mathbf{e}$ shrubs and trees. See Table 3 for statistics
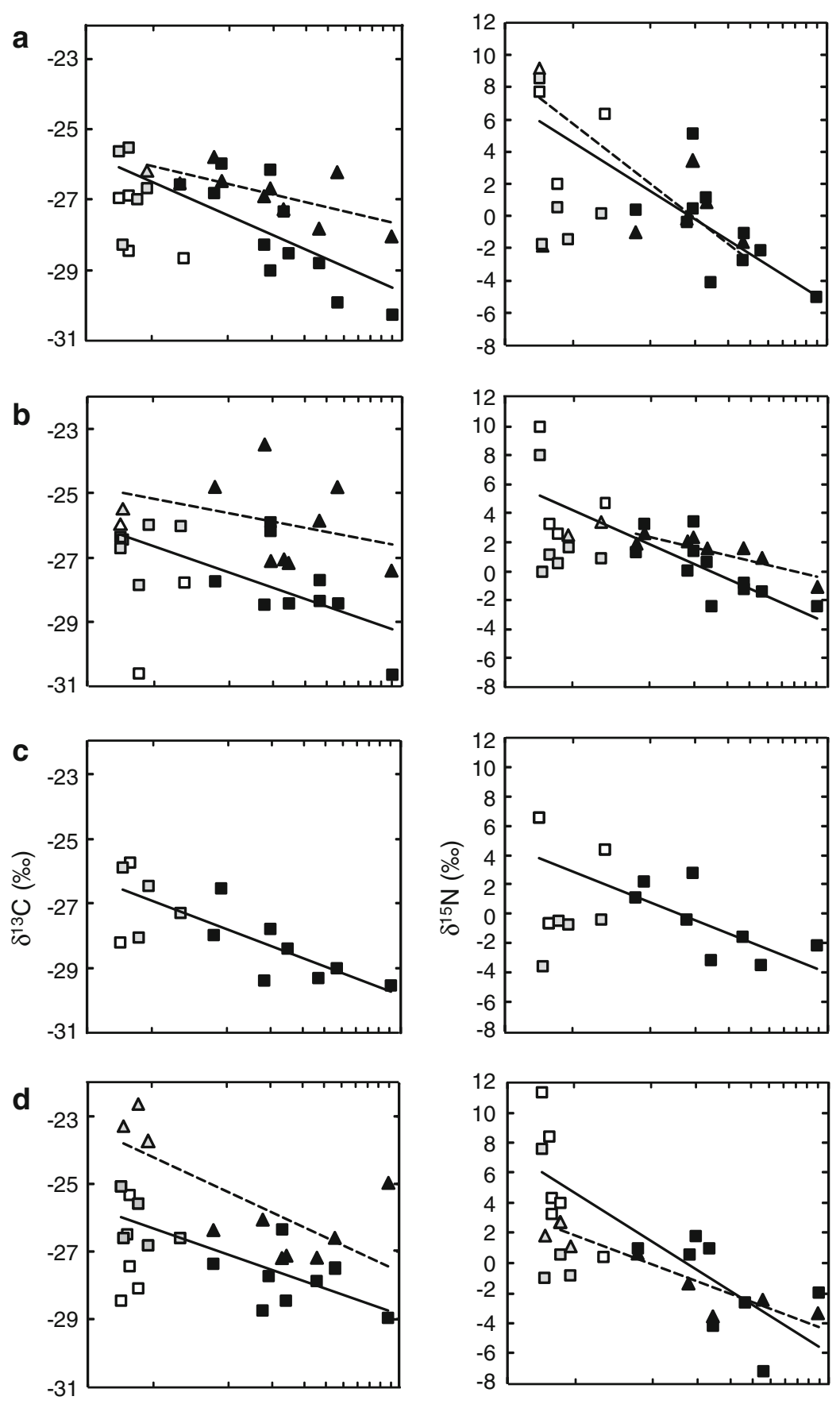

e
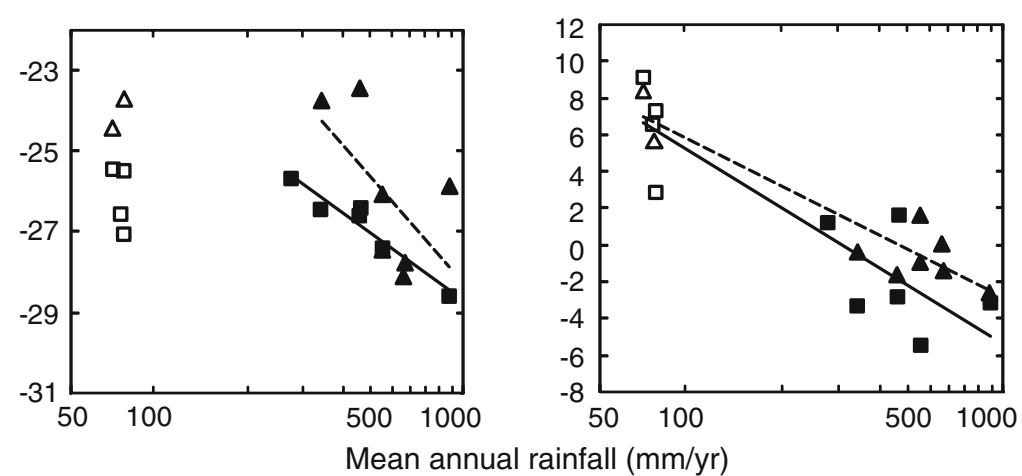
Table 3 Linear regressions of seasonal isotopic composition of plant life forms and mean annual rainfall

\begin{tabular}{|c|c|c|c|c|c|c|c|c|c|}
\hline Life form & $\beta \ln ($ rainfall $)$ & $\alpha$ & $n$ & $R^{2}$ & $P\left(R^{2}\right)$ & $|t|(\beta)$ & $P(\beta)$, & $|t|(\alpha)$ & $P(\alpha)$ \\
\hline \multicolumn{10}{|l|}{ Annuals } \\
\hline \multicolumn{10}{|l|}{$\delta^{15} \mathrm{~N}^{\mathrm{a}}$} \\
\hline W & -3.19 & 19.09 & 16 & 0.65 & $<0.001$ & 1.117 & 0.277 & 1.368 & 0.186 \\
\hline D & -1.82 & 12.21 & 8 & 0.77 & $<0.01$ & & & & \\
\hline \multicolumn{10}{|l|}{$\delta^{13} \mathrm{C}^{\mathrm{b}}$} \\
\hline W & -1.35 & -20.17 & 17 & 0.55 & $<0.001$ & 1.273 & 0.216 & 4.374 & $<0.001$ \\
\hline $\mathrm{D}$ & -0.71 & -22.27 & 10 & 0.48 & $<0.05$ & & & & \\
\hline \multicolumn{10}{|l|}{ Forbs } \\
\hline \multicolumn{10}{|l|}{$\delta^{15} \mathrm{~N}$} \\
\hline W & -4.13 & 24.00 & 13 & 0.63 & $<0.01$ & 0.153 & 0.894 & 0.189 & 0.852 \\
\hline $\mathrm{D}$ & -4.33 & 25.42 & 9 & 0.65 & $<0.01$ & & & & \\
\hline \multicolumn{10}{|l|}{$\delta^{13} \mathrm{C}$} \\
\hline W & -1.04 & -21.73 & 15 & 0.41 & $<0.05$ & 0.581 & 0.568 & 5.388 & $<0.001$ \\
\hline $\mathrm{D}$ & -0.64 & -22.21 & 9 & 0.11 & 0.374 & & & & \\
\hline \multicolumn{10}{|c|}{ Geophytes } \\
\hline \multicolumn{10}{|c|}{$\delta^{15} \mathrm{~N}$} \\
\hline W & -2.68 & 14.78 & 9 & 0.56 & $<0.05$ & & & & \\
\hline \multicolumn{10}{|l|}{$\delta^{13} \mathrm{C}$} \\
\hline $\mathrm{W}$ & -1.22 & -21.27 & 12 & 0.66 & $<0.01$ & & & & \\
\hline \multirow{2}{*}{\multicolumn{10}{|c|}{$\begin{array}{l}\text { Dwarf shrubs } \\
\delta^{15} \mathrm{~N}\end{array}$}} \\
\hline & & & & & & & & & \\
\hline W & -4.71 & 26.95 & 14 & 0.70 & $<0.001$ & 1.451 & 0.162 & 0.933 & 0.361 \\
\hline $\mathrm{D}$ & -2.98 & 16.33 & 10 & 0.81 & $<0.001$ & & & & \\
\hline \multicolumn{10}{|l|}{$\delta^{13} \mathrm{C}$} \\
\hline W & -1.08 & -21.34 & 13 & 0.61 & $<0.01$ & 0.618 & 0.543 & 6.080 & $<0.001$ \\
\hline $\mathrm{D}$ & -1.40 & -17.76 & 11 & 0.49 & $<0.05$ & & & & \\
\hline \multicolumn{10}{|c|}{ Shrubs and trees } \\
\hline \multicolumn{10}{|c|}{$\delta^{15} \mathrm{~N}$} \\
\hline W & -4.49 & 26.03 & 10 & 0.78 & $<0.001$ & 0.799 & 0.437 & 1.371 & 0.189 \\
\hline $\mathrm{D}$ & -3.65 & 22.71 & 9 & 0.87 & $<0.001$ & & & & \\
\hline \multicolumn{10}{|l|}{$\delta^{13} \mathrm{C}$} \\
\hline $\mathrm{W}$ & -2.34 & -12.28 & 6 & 0.92 & $<0.01$ & 0.610 & 0.557 & 2.525 & $<0.05$ \\
\hline D & -2.67 & -3.65 & 7 & 0.35 & 0.159 & & & & \\
\hline
\end{tabular}

$\beta$ Slope, $\alpha$ intercept, $n$ number of sites, $|t|$ paired $t$ test comparing wet and dry season regression line $\beta$ and $\alpha$; for other abbreviations, see Table 2 $P$ values $<0.05$ shown in bold

${ }^{\text {a }}$ Exposed ridge desert sites are excluded from the plant $\delta^{15} \mathrm{~N}$ analysis

${ }^{\mathrm{b}}$ Dry wash desert sites are excluded from the plant $\delta^{13} \mathrm{C}$ analysis

regression slopes. The first group includes dwarf shrubs, and shrubs and trees which have steep regression slopes, while the second group includes annuals and forbs that have mild regression slopes (Table 3). These trends fully correspond with the above division of dry season plants into green (dwarf shrubs; shrubs and trees) and dry (annuals and forbs) groups.

The mean $\delta^{15} \mathrm{~N}$ values of $\mathrm{C}_{3}$ plants collected in both the wet and dry seasons were negatively correlated with rainfall (Table 2). No significant seasonal differences, however, were detected in the $\delta^{15} \mathrm{~N}$ values of $\mathrm{C}_{3}$ plants (paired $t$ test $P=0.166$ ). Furthermore, the regression slopes and intercepts for rainfall on the $\delta^{15} \mathrm{~N}$ values of wet versus dry season $\mathrm{C}_{3}$ plants were indistinguishable (slope $P=0.980$; intercept $P=0.900$; Fig. 2b). A comparison of the slopes of the wet and dry season regression lines for each of the life forms showed no difference (Table 3). In contrast, there is a borderline significant difference among the intercepts of dry season life forms (wet season, slopes $P=0.234$, intercepts $P=0.945 ;$ dry season, slopes $P=0.353$, intercepts 
$P=0.058)$. This difference is the outcome of a significant increase in $\delta^{15} \mathrm{~N}$ values in dry versus wet season plants in the annuals group (paired $t$ test, $P<0.01$; Fig. 4a). Finally, there were no seasonal differences in the $\delta^{15} \mathrm{~N}$ of $\mathrm{C}_{4}$ plants (paired $t$ test, $P=0.624$; regression slopes $P=0.987$, intercepts $P=0.963$; Appendix $\mathrm{C}$ in ESM).

The mean $\mathrm{C} / \mathrm{N}$ ratio of $\mathrm{C}_{3}$ plants increased with increasing rainfall in both seasons (Table 2; Fig. 2c), and also correlated with $\delta^{15} \mathrm{~N}$ values (wet season $R^{2}=0.43$, $P<0.01 ;$ dry season $\left.R^{2}=0.45, P<0.05\right)$. Pronounced seasonal differences were found in the intercepts of the regression lines of $\mathrm{C} / \mathrm{N}$ ratios on rainfall (intercept: $P<0.001$ ), though the slopes were similar (slope $P=0.463)$. Seasonal variation in the $\mathrm{C} / \mathrm{N}$ ratio is mostly related to large changes in $\% \mathrm{~N}(81 \%)$ and only minor changes in $\% \mathrm{C}(8 \%$; Fig. 5). During the wet season, the relative $\mathrm{N}$ content in non-lignified plant parts was much higher than in the dry season (paired $t$ test, $P<0.001$;
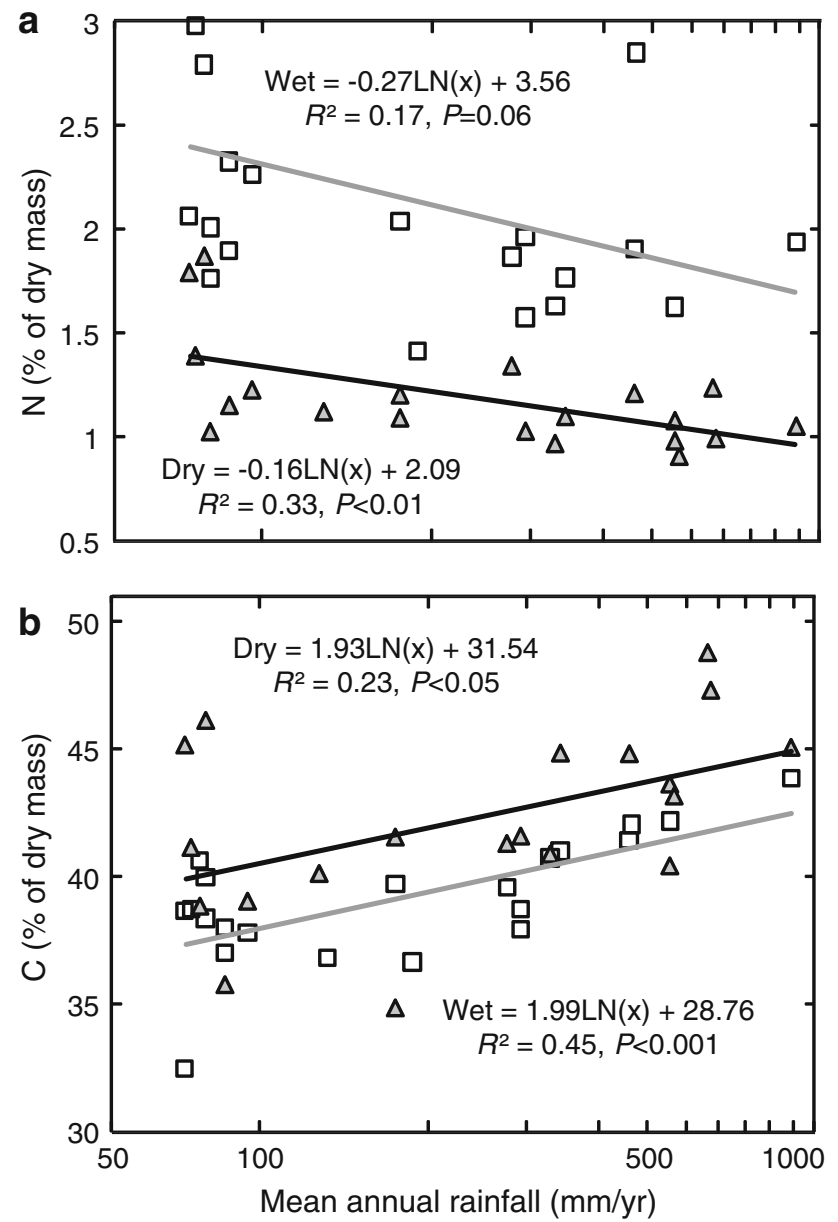

Fig. 5 Seasonal trends and correlation between site means of $\% \mathrm{~N}(\mathbf{a})$ and $\% \mathrm{C}(\mathbf{b})$ and rainfall. Dry season sites indicated by gray triangles, dashed regression line; wet season sites indicated by empty squares, solid regression line. The difference between seasons is significant ( $t$ test, $\% \mathrm{~N} P<0.0001 ; \% \mathrm{C} P<0.01)$
Fig. 5). These differences were not limited to annual plants, but were evident in all other life forms including shrubs and trees which are metabolically active during the dry season (paired $t$ test, annuals $P<0.01$; forbs $P<0.001$; dwarf shrubs $P<0.001$; shrubs and trees $P<0.05)$.

Dry wash versus exposed ridge isotopic distribution in arid environments

The mean $\delta^{13} \mathrm{C}$ values of $\mathrm{C}_{3}$ plants growing in exposed ridge microhabitats were consistently higher than those of plants growing in dry washes from the same sites (paired $t$ test, $P<0.01$; Fig. 6a). The same pattern was observed when comparing the mean $\delta^{13} \mathrm{C}$ values of exposed ridge versus dry wash $\mathrm{C}_{3}$ plants from the same life form (annuals paired $t$ test, $P<0.01$; dwarf shrubs paired $t$ test, $P<0.01$; the absence of shrubs and trees from exposed ridges and
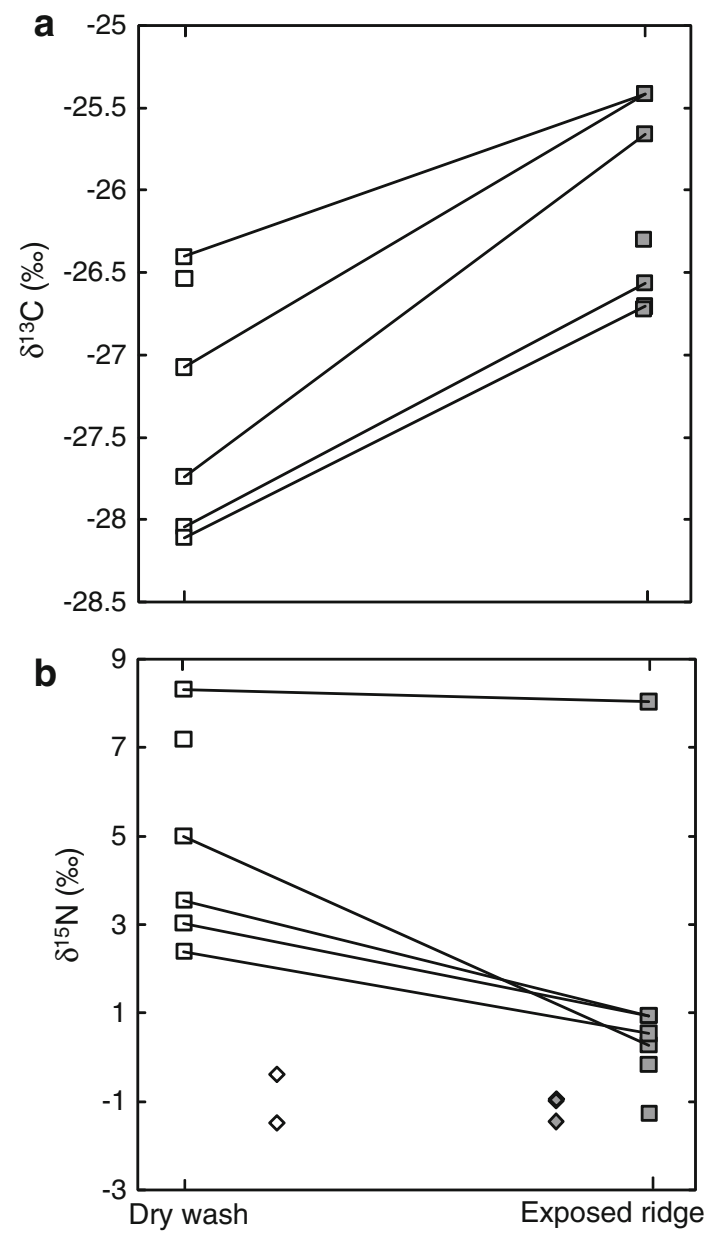

Fig. 6 Mean $\delta^{13} \mathrm{C}$ and $\delta^{15} \mathrm{~N}$ values of $\mathrm{C}_{3}$ plants collected from exposed ridge (closed squares) versus dry wash (open squares) desert sites. Dry wash and exposed ridge wet season samples collected from the same location are linked by lines. a $\delta^{13} \mathrm{C}$ values, $\mathbf{b} \delta^{15} \mathrm{~N}$ values. Legumes (diamonds) in dry wash and exposed ridge sites are also plotted (mean $=-1.05 \pm 0.45 \%$ o, $n=5$ ) 
the near absence of geophytes during the dry season prevented a similar analysis for these life forms). In one case (Metzokei Dragot) a significant difference was measured between annual grasses growing on an exposed ridge and a dry wash located merely $10 \mathrm{~m}$ away (e.g., Stipa capensis dry wash $=-28.2 \%$; exposed ridge $=-24.6 \%$ ). A significant topographic difference also exists when the means of all exposed ridge and all dry wash sites are compared ( $t$ test, $P<0.01$ ).

The effect of topography on $\delta^{15} \mathrm{~N}$ values was much harder to isolate given the wide range of factors contributing to the isotopic pattern of desert soils. Nevertheless, the mean $\delta^{15} \mathrm{~N}$ value of non-N-fixing $\mathrm{C}_{3}$ plants from all dry wash sites was higher than for exposed ridge sites (paired $t$ test, $P<0.05$; Fig. 6b). When divided into life forms similar differences were visible between exposed ridge and dry wash sites (paired $t$ test, annuals $P<0.01$; dwarf shrubs $P<0.01$; but not in forbs, $P=0.204)$. The mean $\delta^{15} \mathrm{~N}( \pm 1 \mathrm{SE})$ value of plants growing on exposed ridges $(1.7 \pm 3.2 \%$ ) is closer to that of $\mathrm{N}$-fixing legumes $(-1.05 \pm 0.5 \%)$ than to that of dry wash plants $(5.23 \pm 2.4 \%$; Fig. $6 \mathrm{~b})$.

In summary, a strong correlation between rainfall and plant $\delta^{15} \mathrm{~N}$ values is found for both seasonal and annual data when site values are averaged or divided by plant life forms. These correlations are maintained despite a significant decrease in the $\mathrm{N}$ content of leaves during the transition from the wet to dry season. A strong correlation is also found between rainfall and plant $\delta^{13} \mathrm{C}$ values when the data are divided into wet and dry seasons. Likewise, the regression formed between the $\delta^{13} \mathrm{C}$ values of dried dry season plants and rainfall is similar to that of wet season plants. The slope of these regression lines is also similar to that of the regression line of green dry season plants and rainfall, but the intercept for the latter is significantly higher. In arid environments, plants growing in dry washes have significantly higher $\delta^{15} \mathrm{~N}$ values and lower $\delta^{13} \mathrm{C}$ values than exposed ridge plants. Finally the slope of the regression line formed between the $\delta^{15} \mathrm{~N}$ values of $\mathrm{C}_{4}$ plants and rainfall is similar to that of $\mathrm{C}_{3}$ plants, but the intercept is significantly higher.

\section{Discussion}

The annual and seasonal relationship between rainfall and $\delta^{13} \mathrm{C}$ values of plants

The results of this study show a significant correlation between annual rainfall and the $\delta^{13} \mathrm{C}$ values of $\mathrm{C}_{3}$ plants collected during the wet season in the Eastern Mediterranean. The same results are obtained for the dry season, but only when green plants are removed from the analysis. The regression line formed between rainfall and dry season green plants is different yet still highly significant. The $\delta^{13} \mathrm{C}$ values of dry season green plants are consistently higher than the values of dry plants, or wet season plants (Fig. 3b). An exception is the desert microhabitat where water availability is influenced more by topography and edaphic factors than by rainfall (Fig. 6a). This pattern was repeated for all plant life forms (Table 3; Fig. 4). The correlation between rainfall and $\delta^{13} \mathrm{C}$ values is evident in both the north-south and eastwest rainfall gradients measured here (Fig. 1). This result supports previous studies reporting that drought stress is a major determinant of $\mathrm{C}$ isotope fractionation in $\mathrm{C}_{3}$ plants on a community level (Stewart et al. 1995; Swap et al. 2004). Regression lines formed between $\ln$ rainfall and the $\delta^{13} \mathrm{C}$ site values for $\mathrm{C}_{3}$ plants in this study are comparable to the trends published for plant communities from other regions (Stewart et al. 1995; Austin and Vitousek 1998; Swap et al. 2004; Zheng and Shangguan 2007; Song et al. 2008; Fig. 7). Unfortunately, $\mathrm{C}$ data have not been compiled to describe a global trend and thus how the data presented here fit a global trend cannot be shown.

In contrast, the $\delta^{13} \mathrm{C}$ values of $\mathrm{C}_{4}$ plants analyzed here are not correlated with rainfall (Appendix B in ESM; for theoretical background see Farquhar 1983). The relative

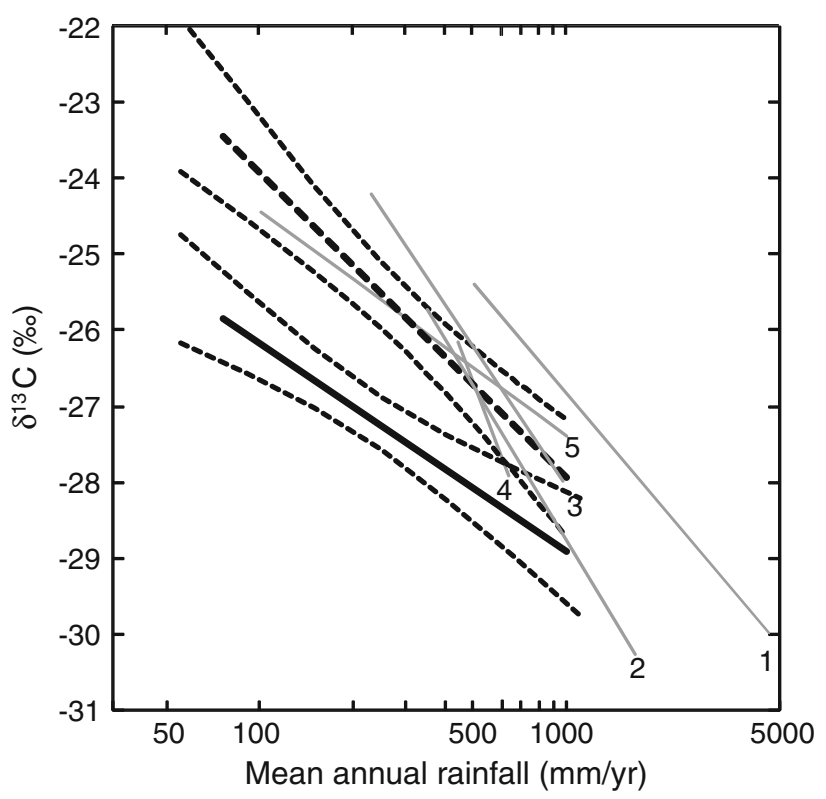

Fig. 7 Regional and local trends in rainfall and $\mathrm{C}_{3}$ plant $\delta^{13} \mathrm{C}$. Linear regression line showing the relationship between wet season $\delta^{13} \mathrm{C}$ values of $\mathrm{C}_{3}$ plant sites (thick black line), and dry season green plants (thick black dashed line), with 95\% confidence intervals indicated (thin black dashed line), both from the current study. These are compared to data collected at other locations in other studies including: Hawaii, $y=-2.07 x-12.51, R^{2}=0.83$ ( 1 Austin and Vitousek 1998); Western Australia, $y=-2.91 x-8.70, R^{2}=0.69$ (2 Stewart et al. 1995); $y=-2.62 x-9.95, R^{2}=0.65$ (3 Swap et al. 2004); China loess plateau, $y=-4.73 x+2.64, R^{2}=0.82$ ( 4 Zheng and Shangguan 2007); and Tibetan Plateau, $y=-1.28 x-18.55$, $R^{2}=0.76$ (5 Song et al. 2008) 
contribution of $\mathrm{C}_{4}$ plants to plant communities, however, is correlated with rainfall in the studied region. $\mathrm{C}_{4}$ plants first become noticeable in areas receiving less than $350 \mathrm{~mm}$ of mean annual rainfall. The number of $\mathrm{C}_{4}$ species increases as annual rainfall decreases (Vogel et al. 1986). The presence of $\mathrm{C}_{4}$ plants in the Eastern Mediterranean is an indicator of arid environments. Further work is needed to establish measures to separate the $\delta^{13} \mathrm{C}$ values of droughtstressed $\mathrm{C}_{3}$ plants from $\mathrm{C}_{4}$ plants in arid environments.

One of the most important results of this study is the strong dichotomy in the $\delta^{13} \mathrm{C}$ values of plants collected in the wet versus dry seasons (Figs. 2a, 4). This pattern was first identified in North American annual grasses and forbs (Smedley et al. 1991; Ehleringer et al. 1992). In this study, this seasonal pattern is recorded in all plant life forms across both north-south and east-west rainfall gradients (Table 3; Fig. 4). It is possible that it derives from the striking seasonal rainfall partitioning in the region of study. Although the gradients are characterized by dramatic differences in rainfall during the wet season, the dry season is hot, dry and prolonged.

The gentle regression slope and weaker correlation between rainfall and the $\delta^{13} \mathrm{C}$ values of dry season plants is a product of combining dry and green plants that co-occur in sample collection sites (Fig. 3). Dry plants better reflect the conditions of the previous rainy season when these plants grew (Fig. 3a). Green plants during the dry season, however, form a separate regression line marked by significantly elevated $\delta^{13} \mathrm{C}$ values compared with those from the wet season (Fig. 3b). This trend suggests that green plants (dwarf shrubs, shrubs and trees) maintain a certain level of metabolic activity under increasing drought stress conditions. Elevated $\delta^{13} \mathrm{C}$ values do not seem to be associated with senescence in dry season mature leaves (Kao et al. 2002). The strong correlation between dry season green plants and rainfall is probably also the combined product of ground water availability, evaporative demand, and improved WUE in desert shrubs and trees. Escudero et al. (2008) demonstrated that long-lived leaves from lignified species have higher $\delta^{13} \mathrm{C}$ values than short-lived leaves, due to reduced transpiration. They argued that this adaptation was designed to combat seasonal and annual shortages of water by minimizing the risk of leaf desiccation. This argument can also be extended to dwarf shrubs that shift from short- to long-lived leaves between the wet and dry seasons (Appendix A).

The relationship between rainfall, $\mathrm{C} / \mathrm{N}$ ratio and plant $\delta^{15} \mathrm{~N}$

The mean $\delta^{15} \mathrm{~N}$ value of non-N-fixing $\mathrm{C}_{3}$ plants is highly correlated with mean annual rainfall when arid exposed ridge sites are excluded from the analysis (see discussion on desert $\mathrm{N}$ below; Table 2; Fig. 2b). The regression lines formed between rainfall and the $\delta^{15} \mathrm{~N}$ values of wet and dry season plants were identical, demonstrating year-round stability in the $\delta^{15} \mathrm{~N}$ isotopic values of $\mathrm{C}_{3}$ plant communities. The correlation between rainfall and plant $\delta^{15} \mathrm{~N}$ values agrees with studies that demonstrated local and global plant ${ }^{15} \mathrm{~N}$ enrichment along negative rainfall gradients (Handley et al. 1999; Swap et al. 2004; Fig. 8). Nevertheless, there is a difference in the regression slope of the Eastern Mediterranean and the regional and global trends that were reported in Handley et al. (1999) and Swap et al. (2004; see also references therein). The wetter sites sampled in this study on average had low $\delta^{15} \mathrm{~N}$ values compared with the global trend, but these values fall within the range of variation reported in the global trend.

The absence of seasonal differences in the $\delta^{15} \mathrm{~N}$ values of all of the $\mathrm{C}_{3}$ plant life forms with the exception of the annual grasses indicates that the physiological response of plants to seasonal drought stress does not cause ${ }^{15} \mathrm{~N}$ enrichment in non-lignified plant stems or leaves. Plant physiology has been argued to be at least partially responsible for increased $\delta^{15} \mathrm{~N}$ values in drought-stressed annual plants in controlled studies (Lopes et al. 2004; Lopes and Araus 2006, for the opposite trend see Robinson et al. 2000). The absence of enrichment in other plant life forms may be related to two processes. First, while annual

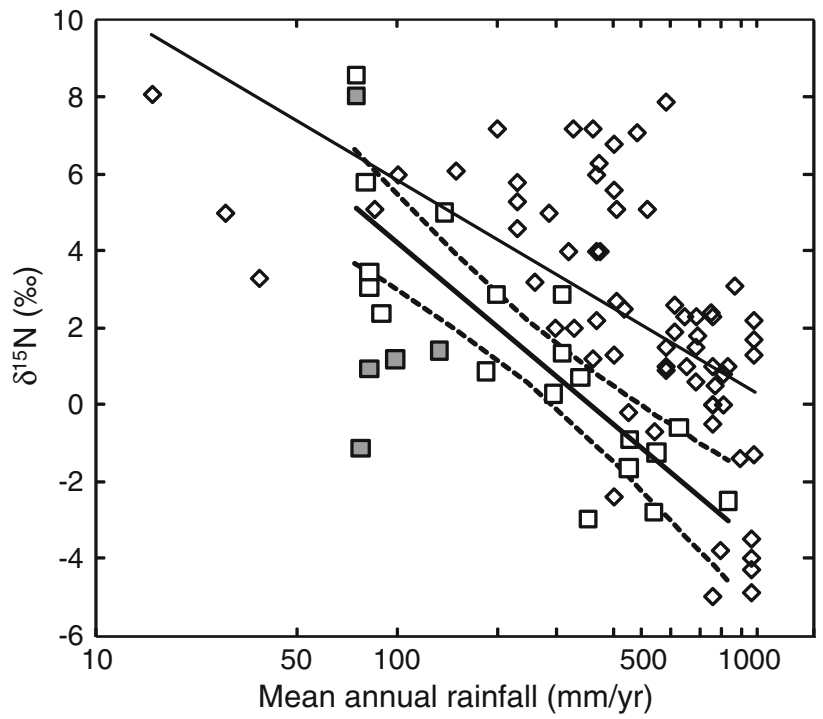

Fig. 8 Global and local trends in the relationship between rainfall and the $\mathrm{N}$ isotopes of $\mathrm{C}_{3}$ plants. Local relationship between rainfall and the annual $\delta^{15} \mathrm{~N}$ values of $\mathrm{C}_{3}$ plant sites (open squares), represented by linear regression line (thick black line) with $95 \%$ confidence intervals (dashed lines). Exposed ridge desert plant sites are indicated by gray squares. Regression line (thin black line) showing the global relationship between rainfall and the $\delta^{15} \mathrm{~N}$ values of $\mathrm{C}_{3}$ plant sites (open diamonds) $n=68, y=-2.22 x+16.07$, $R^{2}=0.36, P<0.0001$ (data taken from Handley et al. 1999; Swap et al. 2004) 
grasses are fully dependent on external $\mathrm{N}$ sources, other plant life forms also use internally stored $\mathrm{N}$ (Chapin et al. 1990). It is possible that the use of internal $\mathrm{N}$ sources late in the growing season dampens the increase in $\delta^{15} \mathrm{~N}$ values. Second, the pattern may be related to the senescence of plant parts. The increase in the $\mathrm{C} / \mathrm{N}$ ratio of dry season plants shown here is primarily caused by a decrease in leaf $\mathrm{N}$ content and is likely associated with senescence of the analyzed plant portions. Perennial plants conserve valuable $\mathrm{N}$ by resorbing it from senescent portions. This process is not accompanied by ${ }^{15} \mathrm{~N}$ enrichment of the senescent parts (Garten 1993; Kao et al. 2002; Kolb and Evans 2002). However, given that $\mathrm{N}$ conservation is not essential in annual plants, $\mathrm{N}$ loss due to senescence may be more pronounced in annuals than in other life forms, leading to higher $\delta^{15} \mathrm{~N}$ values in the dry season. Since the dry season plants were collected late in the season, it cannot be determined whether the lack of internal $\mathrm{N}$ sources or plant senescence caused the observed pattern in annual plants.

Although $\mathrm{C}_{4}$ chenopods had consistently higher $\delta^{15} \mathrm{~N}$ values than $\mathrm{C}_{3}$ plants, the regression slopes of rainfall on the $\delta^{15} \mathrm{~N}$ values of $\mathrm{C}_{3}$ plants were similar to those of $\mathrm{C}_{4}$ plants. To date, only data from Wooller et al. (2005) have shown higher $\delta^{15} \mathrm{~N}$ values in $\mathrm{C}_{4}$ than $\mathrm{C}_{3}$ plants in a given microenvironment (but see Aranibar et al. 2008). Although the explanatory mechanism for this phenomenon remains unclear, the elevation of $\delta^{15} \mathrm{~N}$ values in $\mathrm{C}_{4}$ chenopods must be taken into account when reconstructing the relative contribution of $\mathrm{C}_{4}$ plants to terrestrial food webs.

High $\delta^{15} \mathrm{~N}$ values in arid region plants were accompanied by low $\mathrm{C} / \mathrm{N}$ ratios primarily because of higher $\mathrm{N}$ content in non-lignified portions (Fig. 2). This result is not unexpected since the leaves of plants growing in areas with low annual rainfall are known to have higher $\mathrm{N}$ content per leaf mass than plants growing in wetter conditions (Wright et al. 2004). The low $\mathrm{C} / \mathrm{N}$ ratios and high $\delta^{15} \mathrm{~N}$ values of plants from arid regions and the correlation between $\mathrm{C} / \mathrm{N}$ ratio and plant $\delta^{15} \mathrm{~N}$ values, further strengthen the argument that high plant $\delta^{15} \mathrm{~N}$ values are a product of aridity rather than anthropogenic $\mathrm{N}$ input into the environment.

The isotopic pattern in desert dry washes versus exposed ridges

As expected, the $\delta^{13} \mathrm{C}$ values of plants growing on exposed ridges were higher than those growing in dry washes at the same site, while the opposite was true of the $\delta^{15} \mathrm{~N}$ values (Fig. 6). Variation in water availability caused by topographic differences in arid regions is likely interfering with an otherwise clear relationship between rainfall and plant isotopic composition (Table 2). While significant differences are apparent between dry wash and exposed ridge plants, this study was not designed to investigate the mechanisms that govern these differences. Instead, we propose an explanation for these results based on published data. Dry washes collect water from surrounding areas and are often located closer to aquifers than exposed ridges and thus water availability is much greater than that provided by annual rainfall alone. In addition, in most cases the dry washes are better sheltered from desiccating winds and less exposed to direct solar radiation. Because water availability is heightened in the growing season, dry wash plants can afford to relax water conservation strategies unlike plants growing on exposed ridges that receive water only from rainfall (Ehleringer and Cooper 1988). This results in more negative $\delta^{13} \mathrm{C}$ values in dry wash than exposed ridge plants. The isotopic differences between exposed ridge and dry wash plants were upheld when plants were separated by life form despite diverse water utilization and growth strategies (Fig. 4).

The dichotomy in the $\delta^{15} \mathrm{~N}$ values of desert plants from dry wash versus exposed ridge sites might be related to previously observed differences in $\mathrm{N}$ cycling in semi-arid and arid regions (Hook and Burke 2000; Aranibar et al. 2004; Zaady 2005). The combination of relatively high temperatures and high water availability in dry washes during rain events stimulates the rapid proliferation of soil microorganisms that deplete below-ground oxygen sources (Farrell et al. 1996). Under these temporarily anaerobic conditions, denitrifying bacteria scavenge $\mathrm{O}$ from soil $\mathrm{NO}_{3}$ - causing the rapid volatilization of ${ }^{15} \mathrm{~N}$-depleted $\mathrm{N}_{2}$, thus increasing the $\delta^{15} \mathrm{~N}$ value of the residual soil $\mathrm{N}$ (McKeon et al. 2005). Moreover, the runoff water that concentrates in dry washes also transports more $\mathrm{N}$ further stimulating $\mathrm{N}$ volatilization (Peterjohn and Schlesinger 1991; Zaady and Shachak 1994). The outcome of these processes is the profound ${ }^{15} \mathrm{~N}$ enrichment of the soil in dry washes. The $\mathrm{N}$ from these soils is assimilated by plants growing in dry washes resulting in the patterns of ${ }^{15} \mathrm{~N}$ enrichment shown here. Unlike dry washes, the $\mathrm{N}$ in exposed ridge locations is predominantly supplied by $\mathrm{N}$-fixing microorganisms that inhabit the soil crust as well and by eolian deposition (West 1990; Evans and Ehleringer 1993; Böhlke et al. 1997). The lack of water probably limits further denitrification of soil $\mathrm{N}$ and consequently plants obtain $\mathrm{N}$ depleted in ${ }^{15} \mathrm{~N}$ and more similar to atmospheric $\mathrm{N}$ values.

\section{Conclusion}

The negative relationship between mean annual rainfall and plant $\mathrm{N}$ and $\mathrm{C}$ isotope composition shown in the current study is in agreement with other regional studies. A secondary trend indicating an increase in mean $\delta^{13} \mathrm{C}$ values of dry season $\mathrm{C}_{3}$ plants is attributed to drought stress, which is associated with a decrease in leaf $\mathrm{N}$ content. Mean $\delta^{15} \mathrm{~N}$ 
values, however, remain stable regardless of seasonal drought stress and are likely attributable to long-term processes in soil $\mathrm{N}$ cycling. Variability in the $\delta^{13} \mathrm{C}$ and $\delta^{15} \mathrm{~N}$ values of $\mathrm{C}_{3}$ plants in arid regions is caused by topographic differences in water availability independent of mean annual rainfall. These results indicate that water availability is the primary factor controlling the $\delta^{13} \mathrm{C}$ and $\delta^{15} \mathrm{~N}$ values of plant communities in the Eastern Mediterranean.

Acknowledgments This study was supported by NSF dissertation improvement grant (no. 0643645), a Harvard ASPR Summer Research Grant and a Cora DuBois Fellowship. A plant collection permit was granted to G. H. by the Israel Nature and Parks Authority (permit no. 2007/28558). G. H. would like to thank Dan Yakir, Dan Lieberman, Noreen Tuross, and Natalie Munro for discussions and comments on earlier drafts of the paper, and Hermann Heilmeier and two anonymous reviewers for their extremely helpful comments and suggestions. Finally, G. H. would like to thank Hagar Vered Leshner from the Hebrew University Herbarium and the curatorial staff at Harvard University Herbarium, Adi Ben-Nun from the Hebrew University GIS Center and Bob Michener from Boston University Stable Isotope laboratory for sample analysis.

Open Access This article is distributed under the terms of the Creative Commons Attribution Noncommercial License which permits any noncommercial use, distribution, and reproduction in any medium, provided the original author(s) and source are credited.

\section{References}

Amundson R et al (2003) Global patterns of the isotopic composition of soil and plant nitrogen. Global Biogeochem Cycles 17:1-10

Aranibar JN et al (2004) Nitrogen cycling in the soil-plant system along a precipitation gradient in the Kalahari sands. Glob Change Biol 10:359-373

Aranibar JN et al (2008) Nitrogen isotope composition of soils, $\mathrm{C}_{3}$ and $\mathrm{C}_{4}$ plants along land use gradients in southern Africa. $\mathrm{J}$ Arid Environ 72:326-337

Austin AT, Vitousek PM (1998) Nutrient dynamics on a precipitation gradient in Hawai'i. Oecologia 113:519-529

Bedard-Haughn A, van Groenigen JW, van Kessel C (2003) Tracing ${ }^{15} \mathrm{~N}$ through landscapes: potential uses and precautions. J Hydrol 272:175-190

Böhlke JK, Ericksen GE, Revesz K (1997) Stable isotope evidence for an atmospheric origin of desert nitrate deposits in northern Chile and southern California, USA. Chem Geol 136:135-152

Chapin FS, Schulze ED, Mooney HA (1990) The ecology and economics of storage in plants. Annu Rev Ecol Syst 21:423-447

Comstock JP, Ehleringer JR (1992) Correlating genetic-variation in carbon isotopic composition with complex climatic gradients. Proc Natl Acad Sci USA 89:7747-7751

Craig H (1953) The geochemistry of the stable carbon isotopes. Geochim Cosmochim Acta 3:53-92

Cunningham SA, Summerhayes B, Westoby M (1999) Evolutionary divergences in leaf structure and chemistry, comparing rainfall and soil nutrient gradients. Ecol Monogr 69:569-588

Danin A (1983) Desert vegetation of Israel and Sinai. Cana Publishing House, Jerusalem

Danin A, Orshan G (1990) The distribution of Raunkiaer life forms in Israel in relation to the environment. J Veg Sci 1:41-48
Dawson TE, Mambelli S, Plamboeck AH, Templer PH, Tu KP (2002) Stable isotopes in plant ecology. Annu Rev Ecol Syst 33:507-559

Ehleringer JR, Cooper TA (1988) Correlations between carbon isotope ratio and microhabitat in desert plants. Oecologia 76:562-566

Ehleringer JR, Phillips SL, Comstock JP (1992) Seasonal-variation in the carbon isotopic composition of desert plants. Funct Ecol 6:396-404

Escudero A, Mediavilla S, Heilmeier H (2008) Leaf longevity and drought: avoidance of the costs and risks of early leaf abscission as inferred from the leaf carbon isotopic composition. Funct Plant Biol 35:705-713

Evans RD, Ehleringer JR (1993) A break in the nitrogen-cycle in aridlands: evidence from $\delta^{15} \mathrm{~N}$ of soils. Oecologia 94:314 317

Farquhar GD (1983) On the nature of carbon isotope discrimination in $\mathrm{C}_{4}$ species. Aust J Plant Physiol 10:205-226

Farquhar GD, Richards RA (1984) Isotopic composition of plant carbon correlates with water-use efficiency of wheat genotypes. Aust J Plant Physiol 11:539-552

Farquhar GD, Sharkey TD (1982) Stomatal conductance and photosynthesis. Annu Rev Plant Physiol 33:317-345

Farquhar GD, O'Leary MH, Berry JA (1982) On the relationship between carbon isotope discrimination and the inter-cellular carbon-dioxide concentration in leaves. Aust J Plant Physiol 9:121-137

Farquhar GD, Ehleringer JR, Hubick KT (1989) Carbon isotope discrimination and photosynthesis. Annu Rev Plant Physiol 40:503-537

Farrell RE, Sandercock PJ, Pennock DJ, VanKessel C (1996) Landscape-scale variations in leached nitrate: relationship to denitrification and natural ${ }^{15} \mathrm{~N}$ abundance. Soil Sci Soc Am J 60:1410-1415

Field C, Merino J, Mooney HA (1983) Compromises between wateruse efficiency and nitrogen-use efficiency in 5 species of California evergreens. Oecologia 60:384-389

Garten CT (1993) Variation in foliar ${ }^{15} \mathrm{~N}$ abundance and the availability of soil-nitrogen on Walker Branch watershed. Ecology 74:2098-2113

Goldreich Y (2003) Israel climate: observations research and applications. Springer, New York

Handley LL, Raven JA (1992) The use of natural abundance of nitrogen isotopes in plant physiology and ecology. Plant Cell Environ 15:965-985

Handley LL et al (1999) The ${ }^{15} \mathrm{~N}$ natural abundance $\left(\delta^{15} \mathrm{~N}\right)$ of ecosystem samples reflects measures of water availability. Aust J Plant Physiol 26:185-199

Heaton THE (1987) The N-15/N-14 ratios of plants in South-Africa and Namibia: relationship to climate and coastal saline environments. Oecologia 74:236-246

Högberg P (1997) Tansley review no. $95 .{ }^{15} \mathrm{~N}$ natural abundance in soil-plant systems. New Phytol 137:179-203

Hook PB, Burke IC (2000) Biogeochemistry in a shortgrass landscape: control by topography, soil texture, and microclimate. Ecology 81:2686-2703

Kao WY, Tsai HC, Shih CN, Tsai TT, Handley LL (2002) Nutrient contents, $\delta^{13} \mathrm{C}$ and $\delta^{15} \mathrm{~N}$ during leaf senescence in the mangrove, Kandelia candel (L.) Druce. Bot Bull Acad Sin 43:277-282

Keeling CD, Bollenbacher AF, Whorf TP (2005) Monthly atmospheric $13 \mathrm{C} / 12 \mathrm{C}$ isotopic ratios for 10 SIO stations. In: Trends: a compendium of data on global change. Carbon dioxide information analysis center, Oak Ridge National Laboratory, US Department of Energy, Oak Ridge

Klein $\mathrm{T}$ et al (2005) Association between tree-ring and needle delta ${ }^{13} \mathrm{C}$ and leaf gas exchange in Pinus halepensis under semi-arid conditions. Oecologia 144:45-54 
Kolb KJ, Evans RD (2002) Implications of leaf nitrogen recycling on the nitrogen isotope composition of deciduous plant tissues. New Phytol 156:57-64

Lopes MS, Araus JL (2006) Nitrogen source and water regime effects on durum wheat photosynthesis and stable carbon and nitrogen isotope composition. Physiol Plant 126:435-445

Lopes MS, Nogues S, Araus JL (2004) Nitrogen source and water regime effects on barley photosynthesis and isotope signature. Funct Plant Biol 31:995-1003

McKeon CA, Jordan FL, Glenn EP, Waugh WJ, Nelson SG (2005) Rapid nitrate loss from a contaminated desert soil. J Arid Environ 61:119-136

Peterjohn WT, Schlesinger WH (1991) Factors controlling denitrification in a Chihuahuan Desert ecosystem. Soil Sci Soc Am J 55:1694-1701

Preston T, Owens NJP (1983) Interfacing an automatic elemental analyzer with an isotope ratio mass-spectrometer: the potential for fully automated total nitrogen and ${ }^{15} \mathrm{~N}$ analysis. Analyst 108:971-977

Robinson D, Handley LL, Scrimgeour CM, Gordon DC, Forster BP, Ellis RP (2000) Using stable isotope natural abundances (delta ${ }^{15} \mathrm{~N}$ and delta ${ }^{13} \mathrm{C}$ ) to integrate the stress responses of wild barley (Hordeum spontaneum C. Koch.) genotypes. J Exp Bot 51:41-50

Schulze ED et al (1996) Rooting depth, water availability, and vegetation cover along an aridity gradient in Patagonia. Oecologia 108:503-511

Schulze ED, Turner NC, Nicolle D, Schumacher J (2006) Leaf and wood carbon isotope ratios, specific leaf areas and wood growth of Eucalyptus species across a rainfall gradient in Australia. Tree Physiol 26:479-492

Segal-Rozenhaimer M et al (2004) Sources and transformations of nitrogen compounds along the lower Jordan River. J Environ Qual 33:1440-1451
Smedley MP et al (1991) Seasonal carbon isotope discrimination in a grassland community. Oecologia 85:314-320

Song $\mathrm{MH}$ et al (2008) Leaf delta ${ }^{13} \mathrm{C}$ reflects ecosystem patterns and responses of alpine plants to the environments on the Tibetan Plateau. Ecography 31:499-508

Stewart GR, Turnbull MH, Schmidt S, Erskine PD (1995) ${ }^{13}$ C naturalabundance in plant-communities along a rainfall gradient: a biological integrator of water availability. Aust J Plant Physiol 22:51-55

Swap RJ, Aranibar JN, Dowty PR, Gilhooly WP, Macko SA (2004) Natural abundance of ${ }^{13} \mathrm{C}$ and ${ }^{15} \mathrm{~N}$ in $\mathrm{C}_{3}$ and $\mathrm{C}_{4}$ vegetation of southern Africa: patterns and implications. Glob Change Biol 10:350-358

Vogel JC, Fuls A, Danin A (1986) Geographical and environmental distribution of $\mathrm{C}_{3}$ and $\mathrm{C}_{4}$ grasses in the Sinai, Negev, and Judean Deserts. Oecologia 70:258-265

West NE (1990) Structure and function of microphytic soil crusts in wildland ecosystems of arid to semi-arid regions. Adv Ecol Res 20:179-223

Wooller MJ, Johnson BJ, Wilkie A, Fogel ML (2005) Stable isotope characteristics across narrow savanna/woodland ecotones in Wolfe Creek Meteorite Crater, Western Australia. Oecologia 145:100-112

Wright IJ et al (2004) The worldwide leaf economics spectrum. Nature 428:821-827

Zaady E (2005) Seasonal change and nitrogen cycling in a patchy Negev Desert: a review. Arid Land Res Manage 19:111-124

Zaady E, Shachak M (1994) Microphytic soil crust and ecosystem leakage in the Negev Desert. Am J Bot 81:109

Zar JH (1999) Biostatistical analysis, 4th edn. Prentice Hall, New Jersey

Zheng SX, Shangguan ZP (2007) Spatial patterns of foliar stable carbon isotope compositions of $\mathrm{C}_{3}$ plant species in the Loess Plateau of China. Ecol Res 22:342-353 